\title{
Entrepreneurship Education Inside the Japanese Biosphere Reserve to Trigger Work Opportunities for Youth
}

\author{
Aida Mammadova ${ }^{1}$
}

\begin{abstract}
Entrepreneurship education is defined as the process of providing students with an enhanced capacity to create the ideas and the skills which will be applicable for the future career. From 2018-2019, for four semesters, we have created the regional activities to create the capacity building training program for the exchange students, inside the UNESCO Mount Hakusan Biosphere Reserve (BR) of Japan. Our purpose was to encourage the students to create their own "eco-business projects", and not to search for the jobs provided from the outside. More than 140 students have attended the course, which was divided into volunteering practices, homestay activities and hands-on practices. After the course completion more than $86 \%$ of the students have indicated the willingness to create their own business and some of the students after course completion started their small businesses and worked as freelancers. BR provided the unique platform to conduct the entrepreneurship education, and interacting with local villagers helped the students to re-evaluate the values needed for the sustainable development.
\end{abstract}

Keywords: Entrepreneurship education, Biosphere Reserve, Capacity-Building, Regional sustainable development

\section{Introduction}

The Man and Biosphere Program (MAB) was developed by UNESCO in 1971 with the aim of improving the long-term relationship between people and their ecosystems on a scientific basis (UNESCO, 2020). The MAB program developed the Biosphere Reserve (BR) concept in 1974 as a place where human-nature interactions are tested, perfected, and illustrated, as well as where the MAB program's goals are carried out. Since 1995, all BRs have three main goals: conserving biodiversity, which aims to conserve habitats, ecosystems, plants, and genetic variations; promoting sustainable development, which aims to benefit local communities by fostering social, cultural, and ecological sustainable economic development; and supporting research, monitoring, and education (UNESCO Biosphere Reserves, 1996). Even thought that BRs are considered to be the model sites for the sustainable development, they are facing many challenges and issues such as biodiversity loss, anthropocene, economic instability, conservation issues and others (Stoll-Kleemann and O'Riordan, 2017; Dash and Behera, 2012). Due to high unemployment, many BRs around the world, especially in rural areas, are at risk of depopulation and economic decline. Lack of work prospects is seen as one of the main factors driving youth migration to the major cities and causing the region's socio-economic disparity. The key explanation for youth outflow is that the majority of them are looking 
for an employment from job-givers (Clark \& Summers, 2007), and lack the experience and skills to start their own companies. Entrepreneurship education is one of the areas where students can make transition from work seekers to job creators in today's era of new technology and start-ups. Universities must explore how to shift students' mindsets from job-seekers to job-creators, and allowing them to become self-employed entrepreneurs. Universities need to shift from a mostly scientifically and theoretically oriented curriculum into the one which is more empirical and realistic, and educate the skills such as imagination, innovation, inventiveness, situation analysis, critical thinking, and communication.

Entrepreneurship education has received a lot of attention in recent years, both at universities (Hindle, 2007; Henry et al 2005) and in the social world (George and Reed, 2016). Several elements of entrepreneurship education have been already studied and classified (Hynes, 1996). Informal practices provide instruction, skill creation, and learning from the field, while formal practices concentrate on providing theoretical and conceptual frameworks. It was pointed out that formal and informal education elements are both intertwined, and entrepreneurship education must incorporate all of those elements based on the needs of the individuals.

Eco-entrepreneurship (Schaper, 2002), also known as green entrepreneurship (Allen \& Malin, 2008), is distinct from other types of entrepreneurships, such as social and sustainability. It focuses on three key aspects of sustainable development: economics, equity and the environment, and not just environmental protection (Shepherd \& Patzelt, 2011). Eco-entrepreneurship education bears a significant moral obligation to raise students' environmental consciousness, skills, expertise, and values in order to protect the environment and ensure a sustainable future (Cortese, 2003). Entrepreneurial education, according to Bechard and Toulouse (1998), is " a collection of formalized teachings that informs, trains, and educates anyone interested in participating in socioeconomic development through a project to promote entrepreneurship awareness, business creation, or small business development." One way to enhance the quality of eco-entrepreneurship is to build learning environments where students can directly learn about and observe the entrepreneurs' living environment (Gibb, 2002). UNESCO designated Biosphere Reserves can function as an excellent educational platform for entrepreneurship. BRs may include a variety of realistic lifestyle models in which people use natural resources for economic growth while also protecting the environment in a sustainable manner. In this study we have presumed that real-life experience and hands-on practices with local communities inside BRs, will inspire and empower students with the ability to generate their own ideas and then learn the skills which are necessary to bring those ideas into the reality. Ecoentrepreneurship education inside BRs will provide the awareness, knowledge, and skills needed to start a business and build numerous job opportunities.

\subsection{Mount Hakusan Biosphere Reserve}

Here we focus on the Mount Hakusan Biosphere Reserve (MHBR) in Japan, which is one of Japanese 10 BRs (as for 2021). It was designated by UNESCO's Man and Biosphere Programme in 1980 (UNESCO Mount Hakusan) with only core (alpine/subalpine zones) and buffer zones. After 30 years, in 2016 transition zone was 


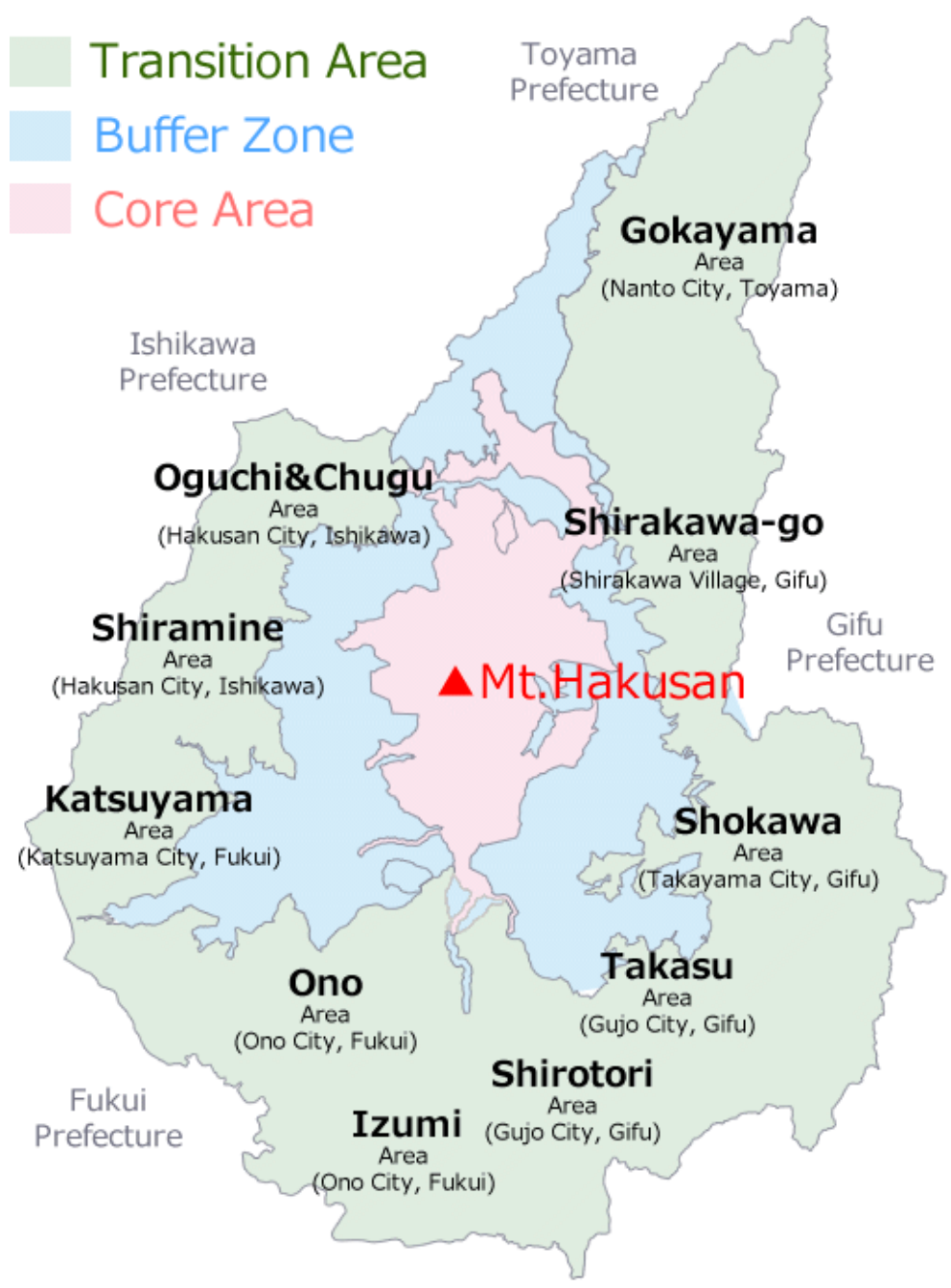

Picture 1. MHBR Zonation and location of Shiramine (source: http:// hakusan-br.jp/english/)

designated with the mountain villages and the settlements of local communities. It is located on the central part of Japanese archipelago, latitude $36^{\circ} \mathrm{N}$ and longitude $137^{\circ} \mathrm{E}$ facing the Sea of Japan side, with the Mt. Hakusan $(2,702 \mathrm{~m})$ on its top. The total area of BR is 199,329ha and population around 17,000 people (UNESCO Mount Hakusan). The area is expanded over the four prefectures Fukui, Ishikawa, Toyama and Gifu. The core area has alpine and subalpine zones and is famous for its endemic vegetation and Japanese beech forest in the buffer zone. Transition zone with hilly and mountainous areas are settled by local villages. In this study, we have conducted our trainings in one villager of MHBR, named Shiramine of Hakusan City, Ishikawa Prefecture.

\subsection{Shiramine Village}


Shiramine is a small village in a mountainous area to the North-East site of Mt. Hakusan and it is included into the transition zone of MHBR (Picture 1). The main differences of the region from the other villages, is that the area has almost no flat lands, and is considered to be the foothills of the Mt. Hakusan with lots of snow precipitation that can reach 2-4 meters. Population in Shiramine is around 800 people. The major industry in Shiramine is forestry and agriculture. This village was also famous for its unique lifestyle, well-learned skills of food preservation practice, charcoal production, specific house construction techniques and gathering medical herbs. Because of its geographical location in the mountainous area next to the Tedori-river, which is flowing from the top of Mt.Hakusan, the village has several dam construction companies and forest management industries. In $1980^{\text {th }}$, the construction of the hydroelectric power plant and innovation of the road infrastructure, resulted in the migration from the mountain areas to the urban cities and nowadays, natural resources management and the mountain landscapes of Shiramine have been rapidly changed and ecosystem services are threatened to be loss, due to the depopulation. After the road constructions local people started to search for the jobs outside the village, rather than managing the farmlands, and gained income provoked to consume the food bought by money. This resulted in the loss of the traditional forest food culture, such as, tree nuts, wild-plants, mushrooms and utilization of the medical herbs was changed into purchasing the medicine from the pharmacies (Mammadova, 2017).

\section{Methods}

From 2018 to 2019, we conducted the first integrated course as part of the curriculum to teach about entrepreneurship and regional sustainable development. Each academic year of the course was divided into two semesters: Spring (April-June) and Autumn (October-March). The total number of the students who attended the courses was 140. All participants were foreign students at undergraduate or graduate level, with different background and age. Together with the local governments, local NGO and MHBR Council, we have carefully designed the curriculum of the training courses for three weeks. One course was divided into three main part for three weeks: first week was theoretical studies inside the university, second week was practical studies inside the MHBR, and the final week was project writing and presentation of the projects. All trips were guided by the professional local instructors and educators.

\subsection{Theoretical studies}

First week, was formal training, where students were provided with the lectures and theoretical background about MHBR, and surrounding regions. The lectures were provided by the academic researchers and the representatives of MHBR Council on the topics below:

- $\quad$ Biosphere Reserves and the International Initiative

- $\quad$ Introduction to the MHBR

- Geological characteristic of Mount Hakusan

- Environmental Communication 
- $\quad$ Environmental and Demographical Issues of Hakusan region

\subsection{Practical studies}

The second week was trainings and practises conducted inside the MHBR. All practises were held inside the transition area of Shiramine village. Transition zone of MHBR was used as the main educational area, where students learned from local communities about sustainable biodiversity management. Students spend 5-6 days in Shiramine village by living together with local villagers and learning about their livelihoods and visiting the local enterprises, business and industry sectors. As a part of experiential learning, students performed the volunteering activities and helped local villagers with their daily jobs. Besides, they learned about the local's culture, food diversity, traditional lifestyle, reginal issues and daily life struggles.

\subsection{Course completion}

At the end of the course, students were requested to "create" their own model of eco-entrepreneurship or business plan, with three main parts: creativity and uniqueness, bio-cultural preservation and international cooperation, and submitted the reports.

\section{Data Collection and Results}

During practical course students conducted the interviews to the local villagers. They were requested to find and record the interconnection between environmental, social and cultural sectors with business opportunities inside the village. The survey was conducted among the students, to evaluate how the fieldtrips and communication with locals raised the awareness about entrepreneurship opportunities and issues to start their own business. Awareness and attitude was scored by $1=$ Very Bad, $2=\mathrm{Bad}, 3=\mathrm{Good}$, $4=$ Very Good, knowledge and skills were employed by Likert scale of four rates $1=$ Strongly Disagree, $2=$ Disagree, $3=$ Agree and 4= Strongly Disagree, and concerns were rates as $1=$ Not concerned at all, $2=$ Somewhat concerned, $3=$ Neutral, $4=$ Concerned, $5=$ Very concerned. Closed-ended questions and multiple choice question were collected, with yes/no replies.

All explanations of the instructors during each trip, were highly appreciated by the students and helped them to deeply understand the local environment and possibilities for entrepreneurship activities (89\%). After the course completion more than $86 \%$ of the students have indicated increased willingness to create their own business. Some students also replied that the perception about Japanese culture was changed. Besides $72 \%$ of students replied that they were strongly agree, that BR helped them to understand about the eco-entrepreneurship opportunities. 86\% replied that community interaction was the most effective way to understand the current situation and possibilities for business creation. Most of the students (72\%) replied that BR increased the ability to analyses the current situation and act towards the needs of the local communities. We also evaluated the attitude/awareness and knowledge/skills to create own business after course completion. Attitude/awareness was increased for $92 \%$, knowledge $45 \%$ and skills $32 \%$. 


\section{Outcomes and discussions}

The majority of Japanese BRs are located in remote areas with limited access, putting them at risk of depopulation and economic decline. Industries, academic institutions, and the government have recently begun to cooperate and work together in order to draw more young people to the region and provide more work places for foreigners (Japan Revitalization Strategy, 2014). Many of these foreigners are not only working or studying in Japan, but also integrate with local communities and contribute for the development of local economy. While Japan has $10 \mathrm{BRs}$, almost none of them provide entrepreneurship education and training for young people, and the majority of them are focused on environmental activities. According to the Lima Action Plan (Lima Action Plan 2016-2025) of MAB, establishing partnerships with universities and creating opportunities for youth to collaborate with local communities are critical for the long-term growth of the BRs.

However, students do not pursue higher education in order to continue their lives in rural areas, but rather dream about the future in big cities. Their primary interest after graduation is to find a job or start working in a well-established companies (Premand et al, 2016). Why are rural areas are unattractive for the young people who want to start a business? The majority of students claim they can't "find" any work opportunities that they would like to do, just because they do not know how to deal with nature and natural resources. Universities, need to change the curriculum with more experiential and handson practices, and raise the skills needed for the entrepreneurship activities. Now, in the era of start-ups and through the eco-entrepreneurship education universities need to take different approach, to allow students to "build" the business that they like instead of "receiving" jobs from job-givers. It was shown that entrepreneurship in Japanese rural areas contributes for the economic reconstruction of rural areas (Haga, 2018). Educating the youth who can create their own business models inside the rural areas will have significant impact to the regional sustainable development.

This study has shown that BRs, can provide the foundation for youth and develop basic knowledge in creating their own business. After the course completion more than $86 \%$ of the students have indicated the willingness to create their own business and some of the students after course completion actually started their own small businesses and work as freelancers. The results have shown that BRs, provided the unique experience-based knowledge with the opportunity to learn directly from the local communities $(72 \%)$. BRs also increased the knowledge $(92 \%)$ and awareness $(45 \%)$ needed to create the small business by using the natural resources. However, the specific skills were not increased $(32 \%)$, and this may indicate that for the skill development longer practices are required. Also, the involvement of young students in creating eco-entrepreneurship encouraged the local communities to re-evaluate the regional resources and stimulated to create new startup projects. Students replied that the interaction with the locals was very effective to gain the information on current situation $(72 \%)$ and motivated to act towards the regional issues. BR served as a good platform to create the dialog where local people shared their lifestyle with the younger generation and helped to reflect the current state of job opportunities inside BRs. Strong and weak sides of the communities were analyzed by the students to create the eco-enterprises. From the submitted reports, many ideas were 
collected on how to reach the regional sustainable development and attract more youth to create their own business by using the natural resources of the region.

- International tourism agency for eco-camping and trekking

- $\quad$ Leisure are recreational activities to attract more kids

- $\quad$ Agencies to promote healthy lifestyles from the rural areas

- Waste-recycling factory working together with educational and social structures

- $\quad$ Creating waste and water treatment organization

- $\quad$ Recycling factories inside the village

- $\quad$ Dam constructing company, to prevent the landslides in the mountain area

- $\quad$ Small self-sufficient organic farms to attract foreign tourist

- $\quad$ Eco-entrepreneurship with agricultural sectors, such as crop planting factories

- $\quad$ Forest management and wood exports

\section{Conclusion}

The results of this study showed that learning directly from the local communities inside BRs, helped to increase the awareness about eco-entrepreneurship opportunities in youth. Besides, this study contributed in creating the dialog between the diverse youth groups and local villagers, and provided the platform to reflect the current state of job opportunities, as well as helped to find the strongest and the weakest sides of the region in order to create eco-enterprises.

This kind of training inside BR, in future will contribute to increase the involvement of the youth to deal with the problems as depopulation and lack of human resources, as well as contribute to create new strategies and policies for sustainable management of BRs.

\section{Reference}

Allen, J. C., \& Malin, S. (2008). Green entrepreneurship: a method for managing natural resources?. Society and natural resources, $21(9), 828-844$.

Batisse, M. (1997). Biosphere reserves: a challenge for biodiversity conservation \& regional development. Environment: Science and Policy for Sustainable Development, 39(5), 6-33.

Bechard, J. P., \& Toulouse, J. M. (1998). Validation of a didactic model for the analysis of training objectives in entrepreneurship. Journal of business venturing, 13(4), 317-332.

Clark, K. B., \& Summers, L. H. (2007). 7. The Dynamics of Youth Unemployment (pp. 199-234). University of Chicago Press.

Cortese, A. D. (2003). The critical role of higher education in creating a sustainable future. Planning for Higher Education, March-May, 2003.

Dash, M., \& Behera, B. (2012). Management of similipal biosphere reserve forest: Issues and challenges. Advances in Forestry Letter (AFL), 1(1), 7-15.

George, C., \& Reed, M. G. (2016). Building institutional capacity for environmental governance through social entrepreneurship: lessons from Canadian biosphere reserves. Ecology and Society, 21(1).

Gibb, Allan. (2002). Creating conducive environments for learning and entrepreneurship: living with, dealing with, creating and enjoying uncertainty and complexity. Industry and Higher Education, 16(3), 135148.

Haga, K. (2018). Innovation in rural Japan: entrepreneurs and residents meeting the challenges of aging and shrinking agricultural communities. Journal of Innovation Economics Management, (1), 87-117. 
Henry, C., Hill, F., \& Leitch, C. (2005). Entrepreneurship education and training: can entrepreneurship be taught? Part I. Education+ Training.

Hindle, K. (2007). Teaching entrepreneurship at university: from the wrong building to the right philosophy. Handbook of research in entrepreneurship education, 1, 104-126.

Hynes, Briga (1996), Entrepreneurship education and training introducing entrepreneurship into non-business disciplines, Journal of European Industrial Training, Vol. 20 Iss 8 pp. 10 - 17

Japan Revitalization $\quad$ Strategy (2014) from https://www.kantei.go.jp/jp/singi/keizaisaisei/pdf/honbunEN.pdf(accessed in April, 2021)

Lima Action Plan (2015-2025), Retrieved from http://www.unesco.org/new/en/naturalsciences/environment/ecological-sciences/man-and-biosphere-programme/strategy-and-actionplan/new-mab-strategy-and-action-plan/documents/, May 2020

Mammadova, A. (2017). Biosphere reserve as learning sites for biocultural conservation education; Case of Mount Hakusan Biosphere Reserve in Japan. European Journal of Sustainable Development, 6(4), 487-487.

Premand, P., Brodmann, S., Almeida, R., Grun, R., \& Barouni, M. (2016). Entrepreneurship education and entry into self-employment among university graduates. World Development, 77, 311-327.

Schaper, Michael. "The essence of ecopreneurship." Greener management international (2002): 26-30.

Shepherd, D. A., \& Patzelt, H. (2011). The new field of sustainable entrepreneurship: Studying entrepreneurial action linking "what is to be sustained" with "what is to be developed". Entrepreneurship theory and practice, 35(1), 137-163.

Stoll-Kleemann, S., \& O'Riordan, T. (2017). The challenges of the Anthropocene for biosphere reserves. Parks, 23(1), 89-100.

UNESCO Biosphere reserves (1996) "The Seville strategy \& the statutory framework of the world network" Paris (1996) http://unesdoc.unesco.org/images/0010/001038/103849Eb.pdf. (Accessed April 15, 2021)

UNESCO Biosphere Reserves (2020), https://en.unesco.org/biosphere (Accessed April 15, 2021)

UNESCO Mount Hakusan, Retrieved from http://www.unesco.org/new/en/naturalsciences/environment/ecological-sciences/biosphere-reserves/asia-and-the-pacific/japan/mounthakusan/, (Acceded May 10, 2021) 